\title{
DIMENSIONS OF LEADERSHIP IN A SIMULATED COMBAT SITUATION
}

\author{
William H. Helme, Louis P. Willemin, \\ and Frances C. Grafton \\ BEHAVIORAL EVALUATION RESEARCH DIVISION \\ William H. Helme, Chief
}

\section{BEHAVIOR AND SYSTEMS RESEARCH LABORATORY}

Office, Chief of Research and Development

Department of the Army

1300 Wilson Boulevard, Arlington, Virginia 22209

July 1971 